\title{
サーマルマネキンの等価温度を用いた暖房の快適性評価と室内投入熱量 THERMAL COMFORT AND ENERGY INPUT OF HEATING SYSTEM BASED ON EQUIVALENT TEMPERATURE OF A THERMAL MANIKIN
}

\author{
篠原愛美*, 田辺新一**, 鍵 屋 慎一***, 松前和則**** \\ Manami SHINOHARA, Shin-ichi TANABE, Shin-ichi KAGIYA \\ and Kazunori MATSUMAE
}

\begin{abstract}
Recently, residences are becoming more insulated and airtight for energy saving action. In such residences, floor heating (radiative system) and air conditioner (convective system) have become widely used. So the thermal comfort in rooms heated by floor heating or air conditioner was compared by the thermal manikin. The experiment for the thermal manikin was performed in the artificial climate chamber. When sensible heat loss became thermal neutrality, the thermal comfort in rooms heated by floor heating or air conditioner was compared by air temperature. In the result, for all conditions air temperature by floor heating was lower than that by air conditioner.
\end{abstract}

Keywords : Thermal Manikin, Thermal Comfort, Energy Input, Heating Systems, Equivalent Temperature サーマルマネキン，熱的快適性，投入熱量，暖房，等価温度

\section{1. はじめに}

日本の住宅は、断熱性や気密性が低いものが多かったが、省エネ ルギーや居住空間の快適性向上のために住宅の高断熱化が推進され、 高断熱・高気密型住宅の普及が進められてきた。居住空間における 快適性一の要求も高まり、住宅においても床暖房などの放射式暖房 が採用されるようになっている。

近年、住宅においては省エネルギー性向上のために多くの手法が 提案・導入されるようになった。その効果を適切に評価するには居 住者の熱的快適性を基準とすることが望まれる。異なる暖房方式に よって形成される室内環境の熱的快適性を適切に評価・比較するた めには、室温のみの評価では不十分であり、人体と環境との熱交換 を考慮する必要がある。実際の暖房空間の熱的快適性評価のために 室温分布や気流分布を測定した研究は多くあるが、人体形状を考慮 した研究は少ない。被験者実験も貴重なデータを提供してくれるが、 その相違の理由を検討するためには人体と環境との熱交換を詳細に 知る必要がある。本研究では、人体形状をしたサーマルマネキンを 用いて人体と環境との熱交換を直接測定することで、環境が人体に 与える影響をより詳細に解析し、住宅性能や暖房方式により形成さ れる温熱環境を、サーマルマネキンによる放熱量を基準として評価 した。また、熱的に等価な条件で、熱的快適性を評価基準とした室 内投入熱量に関しても考察を行った。

\section{2. 暖房方式と熱的快適性に関する既往研究}

B.W.Olesen 5 2)は非常に良く断熱された居室（熱貫流率：床 $=0.20 \mathrm{~W} /\left(\mathrm{m}^{2} \mathrm{~K}\right)$ 、天井・側壁 $=0.25 \mathrm{~W} /\left(\mathrm{m}^{2} \mathrm{~K}\right)$ 、正面壁 $\left.=0.35 \mathrm{~W} /\left(\mathrm{m}^{2} \mathrm{~K}\right)\right)$ を対象に、放射パネル・対流暖房・床暖房・天井暖房などの 9 種類 の異なる暖房方式による温熱環境について、等価温度が同一になる 条件において被験者実験を行い、熱的快適性を評価した。その結果、 非常に良く断熱された居室では、いずれの暖房方式においても同様 に快適な温熱環境が形成されることがわかったとしている。

秋元ら ${ }^{3)}$ は無断熱の鉄筋コンクリート造の居間を対象に、低温ふ く射パネル・温風暖房器・床カーペットを設置し、居住域の PMV (Predicted Mean Vote) が 0 に制御された時の温熱環境・電気工 ネルギー消費量と、投入エネルギー量が一定時の PMV・平均室温 を測定した。その結果、電気温風暖房器を室内上部に設置した場合 は、上下温度分布が大きくなり、エネルギー消費量が他条件より大 きくなり、室内下部に設置した場合は、気流が大きくなり居住者に 不快感を与える可能性があるとしている。また、温風暖房を室内上 部に設置すると暖房方式としてかなり不利と考えられるとしている。

田辺ら ${ }^{4)}$ は鉄骨十木造平屋建ての断熱性の高い実際の建物（熱損 失係数 $\mathrm{Q}$ 值 $\left.=2.49 \mathrm{~W} /\left(\mathrm{m}^{2} \mathrm{~K}\right)\right)$ において、電気ヒーター・ふく射パネ ル・温風暖房器などの 9 種類の暖房方式による温熱環境について、 居住域の PMV が 0 に制御された時の室内温度分布・快適性・エネ

\footnotetext{
* 東京ガス(株) 工修 (当時 早稲田大学大学院創造理工学研究科建築学専攻 修士）

** 早稲田大学創造理工学部建築学科 教授. 工博

*** 東京ガス(侏) 工博

**** 東京ガス(侏) 工修

Tokyo Gas Co., Ltd., M. Eng.

(Former Graduate Student, Dept. of Architecture, Waseda University)

Prof., Dept. of Architecture, Waseda University, Dr. Eng.

Tokyo Gas Co., Ltd., Dr. Eng.

Tokyo Gas Co., Ltd., M. Eng.
} 
ルギー消費量を測定した。その結果、暖房機器の快適性はその放熱 能力のみではなく、設置場所やそれぞれの暖房機器により形成され る室内環境を含めて考慮する必要があり、空気温度だけではなく気 流や平均ふく射温度も含めて環境評価を行う必要があるとしている。 須藤ら ${ }^{5)}$ は人工気候室内に建てられた R-2000 住宅技術基準IV地 域と旧省エネルギー基準IV地域に適合する断熱性能の居室を対象に、 パネルヒーター・対流暖房・床暖房などの 5 種類の異なる暖房方式 による温熱環境について、居室の PMV が 0 になるような条件にお いて ISO-7730 を基準に快適性を評価し、エネルギー消費量を測定 した。その結果、快適と判断されたのは、R-2000 住宅技術基準の 居室では、全ての暖房方式であったが、旧省エネルギー基準の居室 では、パネルヒーターと床暖房のみであったとしている。

大森ら ${ }^{6)}$ はIV地域における旧省エネルギー基準・次世代省エネル ギー基準を満たす断熱性能の住宅を対象に、床暖房とエアコンによ る温熱環境について、対流・放射連成シミュレーションによって ISO-7730 を基準にして室内温熱環境を総合評価した。その結果、 どちらの断熱性能においても床暖房がエアコンよりもやや快適であ ったとしている。簡易的な人体モデルを含めたシミュレーションに おいても同様の結果を得ている。また、投入熱量に関しては、全て の条件においてェアコンよりも床暖房の方が少ない結果であったと しているが、このシミュレーションでの床暖房の投入エネルギー量 は室内への放熱量だけが考慮されており、床下への放熱量が考慮さ れておらず、それらを考慮したシミュレーションを行うことが必要 であるとしている。

坂口ら 7)は北陸地方に実際に建てられた断熱性能の高い住宅 $(\mathrm{Q}$ 值 $\left.=2.13 \mathrm{~W} /\left(\mathrm{m}^{2} \mathrm{~K}\right)\right)$ において、居住者が快適と感じるような設定温度 での床暖房とエアコンの室内総発生熱量（暖房出力と家電機器の熱 量の総和）を測定し、また数值流体解析を行い標準新有効温度 SET* が $22^{\circ} \mathrm{C}$ となる条件での居室の各壁面を通過する熱の収支を詳細に 算出した。その結果、室内総発生熱量はエアコンより床暖房の方が 少ないことがわかったとしている。また、シミュレーションの結果、 床暖房では床面の放射によりエアコンと比較して壁面温度が上昇寸 るため、屋外に面する壁面や空面の貫流熱が増加するとしている。 さらに、床以外の断熱性能を低下させた条件で解析を行った結果、 全ての部位の断熱性能を低下させた条件と比較して、エアコンでは 損失熱量が減少するが、床暖房ではあまり変化がないことがわかっ た。また、床暖房では床暖房パネルの温度が高いため床下部分の断 熱強化が特に必要であるとしている。

以上のように、多くの既往研究では PMV や $\mathrm{SET}^{*}$ 等の環境の物 理值を基準として室内環境を評価しており、人体形状を考慮し、人 体と環境との熱交換の視点から室内環境を評価したものは少ない。 本研究ではサーマルマネキンを用いることで人体形状を考慮し、人 体と環境との熱交換の視点から暖房空間の熱的快適性評価を行う。

\section{3. 実験概要}

\section{1 実験対象居室}

図 1 に実験対象居室、図 2 に実験住宅を示す。実験は、 $\mathrm{T}$ 社横浜 研究所の人工気候室内に設置された実験住宅 8 )のリビングで行われ た。リビングは実験住宅の南側にある奥行 $4,095 \mathrm{~mm} \times$ 幅 $5,460 \mathrm{~mm}$ ×高さ $2,400 \mathrm{~mm}$ (13.5 畳) の空間である。リビングの南側に掃き
出し空（幅 $1,640 \mathrm{~mm} \times$ 高さ $2,000 \mathrm{~mm} ） を 2 つ$ 設置し、それぞれに カーテンを設置した。西壁の床上 $1,600 \mathrm{~mm}$ の位置に給気口（ $\phi$ $90 \mathrm{~mm})$ 、北壁の床上 $150 \mathrm{~mm}$ の位置に排気口 $(\phi 90 \mathrm{~mm})$ を設置し、 換気回数が 0.5 回/h になるように設定した。また、給気用シリンダ 一（ $\phi 18 \mathrm{~mm} ）$ を南壁に 8 箇所、西壁に 16 箇所設置し、隙間相当 面積（C 值）を $2.75 \mathrm{~cm}^{2} / \mathrm{m}^{2}$ とした。また、開口部外表面の放射温 度を外気温度と同じにするために、開口部の外側にファンとカーテ ンを設置した。

リビングには床暖房パネル $(2,380 \mathrm{~mm} \times 3,290 \mathrm{~mm})$ が 2 枚設置さ

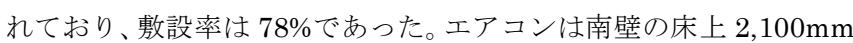
に設置されており、吹出し方向は鉛直下方から $30^{\circ}$ の向きとした。

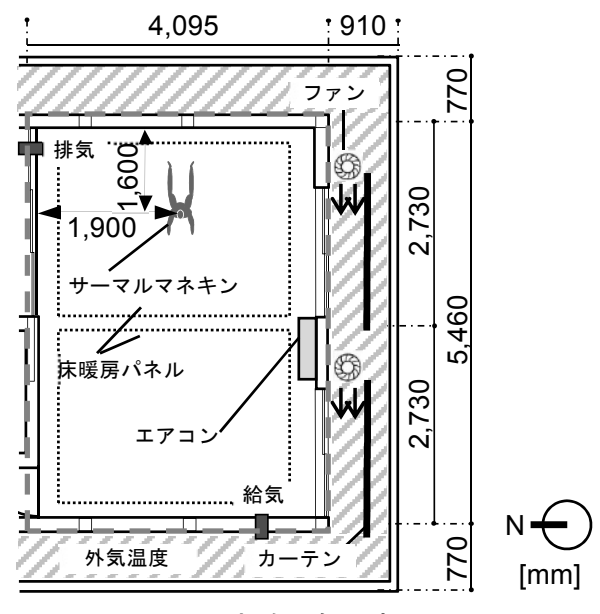

図 1 実験対象居室

\section{2 暖房方式}

暖房方式は、床暖房またはエアコンとした。エアコン使用時は、 床面からの熱拡散を考慮し床暖房パネル内の水を抜いて行った。表 1 に実験条件を示す。

表 1 実験条件

\begin{tabular}{|c|c|c|c|}
\hline 暖房方式 & 設定温度 $\left[{ }^{\circ} \mathrm{C}\right]$ & 姿勢 & 断熱性能[W/(m $\left.\left.{ }^{2} \mathrm{~K}\right)\right]$ \\
\hline \multirow{8}{*}{ 床暖房 } & $18 \cdot 22$ & \multirow{5}{*}{ 投げ足 } & 2.46 \\
\hline & \multirow{3}{*}{$18 \cdot 20 \cdot 22 \cdot 24$} & & 2.70 \\
\hline & & & 3.04 \\
\hline & & & 3.30 \\
\hline & $18 \cdot 24$ & & 3.72 \\
\hline & $18 \cdot 20 \cdot 22 \cdot 24$ & \multirow{3}{*}{ 椅子座 } & 2.70 \\
\hline & $18 \cdot 24$ & & 3.04 \\
\hline & $20 \cdot 24$ & & 3.30 \\
\hline \multirow{7}{*}{ エアコン } & \multirow{3}{*}{$18 \cdot 20 \cdot 22 \cdot 24$} & \multirow{5}{*}{ 投げ足 } & 2.70 \\
\hline & & & 3.04 \\
\hline & & & 3.10 \\
\hline & $20 \cdot 22 \cdot 24 \cdot 26$ & & 3.30 \\
\hline & $20 \cdot 26$ & & 3.72 \\
\hline & $18 \cdot 20 \cdot 22 \cdot 24$ & \multirow{2}{*}{ 椅子座 } & 2.70 \\
\hline & $22 \cdot 26$ & & $\frac{3.04}{3.30}$ \\
\hline
\end{tabular}

\section{3 設定温度}

省エネルギー基準の地域区分IV 地域の冬季を想定し、外気温度の 設定は $5^{\circ} \mathrm{C}$ 、相対湿度 $40 \%$ とした。表 1 に示寸ように、床暖房条件 では $18 \sim 24^{\circ} \mathrm{C}$ 、エアコン条件では $18 \sim 26^{\circ} \mathrm{C}$ の各設定温度とした。 床暖房では図 2 中の測定点 12 近傍に設置されたポールの床上高さ $1,100 \mathrm{~mm}$ に取り付けられたりモコン内温度センサー、エアコンは 3.1 で述べた位置に設置されたエアコンに取り付けられた温度セン サーで測定された温度が設定温度として制御された。

\section{4 断熱性能}

実験対象居室の壁面断熱構成は、室内側からせっこうボード 


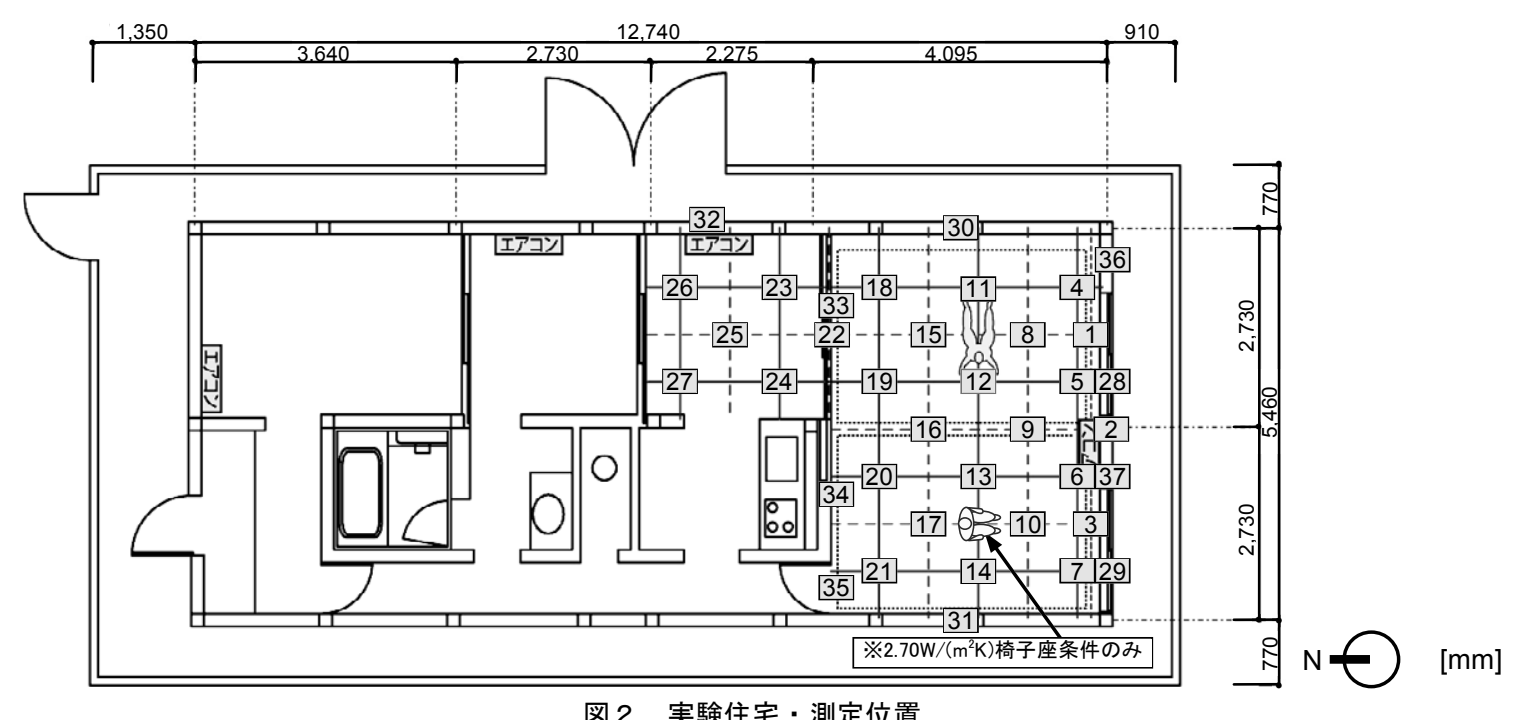

図 2 実験住宅・測定位置

$(12.5 \mathrm{~mm}) \cdot$ 押出法ポリスチレンフォーム 3 種 $(50 \mathrm{~mm})$ ・ダイラ イト $(9 \mathrm{~mm})$ である。断熱性能は、新省エネルギー基準のIV地域基 準（基準值=3.95W/(m² $\mathrm{K})$ ）を満たすように、3.04・3.10・3.30・ $3.72 \mathrm{~W} /\left(\mathrm{m}^{2} \mathrm{~K}\right)$ の 4 条件に設定した。また、次世代省エネルギー基準 （基準值 $=2.70 \mathrm{~W} /\left(\mathrm{m}^{2} \mathrm{~K}\right)$ ) を満たす高断熱条件として 2.46 ・ $2.70 \mathrm{~W} /\left(\mathrm{m}^{2} \mathrm{~K}\right)$ の断熱性能の条件でも実験を行った。

断熱性能による実験室仕様の違いを表 2 に示す。開口部に関して、 断熱性能が $2.46 \sim 3.10 \mathrm{~W} /\left(\mathrm{m}^{2} \mathrm{~K}\right)$ 条件ではカーテンを閉めて空ガラス はペアガラスとし、3.30・3.72W/(m $\left.{ }^{2} \mathrm{~K}\right)$ 条件ではカーテンを開けて 空ガラスはシングルガラスとした。床下温度が実際よりも低くなる ため、 $3.04 \mathrm{~W} /\left(\mathrm{m}^{2} \mathrm{~K}\right)$ 以外の条件では実際の住宅を考慮し、室外と床 下との間に模擬基礎を設置した。2.46・2.70・3.04W/(m² $\mathrm{K})$ 条件で は東壁の外側に、外断熱材として押出法ポリスチレンフォーム 3 種 $(50 \mathrm{~mm})$ を設置した。また、 $2.46 \mathrm{~W} /\left(\mathrm{m}^{2} \mathrm{~K}\right)$ 条件では空ガラスの外 側にも断熱材を設置した。3.72 W/ $\left(\mathrm{m}^{2} \mathrm{~K}\right)$ 条件では隣室暖房は行わず、 隣室の空を開けた条件で行った。隣室暖房を行う場合は、隣室に設 置したエアコンの設定温度を $20^{\circ} \mathrm{C} に し て$ 行った。設定温度としてエ アコンに取り付けられた温度センサーにおける測定温度を制御した。

\section{表 2 断熱性能による実験室仕様の違い}

\begin{tabular}{c|c|c|c|c|c|c}
\hline & \multicolumn{5}{|c}{ 断熱性能 $\left[\mathrm{W} /\left(\mathrm{m}^{2} \mathrm{~K}\right)\right]$} & \\
\cline { 2 - 8 } & 2.46 & 2.70 & 3.04 & 3.10 & 3.30 & 3.72 \\
\hline \hline カーテン & $\bigcirc$ & $\bigcirc$ & $\bigcirc$ & $\bigcirc$ & $\times$ & $\times$ \\
\hline シングルガラス(空面) & $\times$ & $\times$ & $\times$ & $\times$ & $\bigcirc$ & $\bigcirc$ \\
\hline ペアガラス(空面) & $\bigcirc$ & $\bigcirc$ & $\bigcirc$ & $\bigcirc$ & $\times$ & $\times$ \\
\hline 模擬基礎 & $\bigcirc$ & $\bigcirc$ & $\times$ & $\bigcirc$ & $\bigcirc$ & $\bigcirc$ \\
\hline 東壁外断熱材 & $\bigcirc$ & $\bigcirc$ & $\bigcirc$ & $\times$ & $\times$ & $\times$ \\
\hline 空面外断熱材 & $\bigcirc$ & $\times$ & $\times$ & $\times$ & $\times$ & $\times$ \\
\hline 隣室暖房 & $\bigcirc$ & $\bigcirc$ & $\bigcirc$ & $\bigcirc$ & $\bigcirc$ & $\times$ \\
\hline
\end{tabular}

\section{5 測定項目}

測定項目を表 3 に示す。温熱環境として、空気温度・表面温度・ グローブ温度・気流速度を測定した。上下温度分布として空気温度 および表面温度を、床下表面から屋根表面まで表 3 の各位置で測定 した。また、壁面からの放射の影響を測定するために、直径 $40 \mathrm{~mm}$ の小型グローブ温度を床面 $+100 \mathrm{~mm}$ と $+1,100 \mathrm{~mm}$ のつの高さで測 定した。気流速度は床面 $+600 \mathrm{~mm}$ と $+1,100 \mathrm{~mm}$ の 2 つの高さで測定 した。測定位置は図 2 中に数字で示した各点とした。ただし、断熱 性能 $2.70 \mathrm{~W} /\left(\mathrm{m}^{2} \mathrm{~K}\right)$ 条件では測定位置 $4,7,9,11,14,16,18,21$ における
空気温度・表面温度・グローブ温度の測定と、気流速度の測定を行 わなかった。

3.6 サーマルマネキン

図 3 に本実験で使用したサーマルマネキンを示す9)。断熱性能 $2.70 \mathrm{~W} /\left(\mathrm{m}^{2} \mathrm{~K}\right)$ の条件では b のサーマルマネキンが、その他の条件で は a のサーマルマネキンが使用された。両サーマルマネキンは、分 割数は異なるが、同じ形状、構造、制御方法を採用しており、同様 の方法で校正されており、サーマルマネキン間の差異は非常に小さ いと考えられる。サーマルマネキンのシェルはポリエステル製で、 $4 \mathrm{~mm}$ 厚のグラスファイバーで補強されている。 $0.3 \mathrm{~mm} \phi$ のニッケ ルワイヤーが $2 \mathrm{~mm}$ 以下の間隔で全身に巻かれており、このワイヤ 一により温度計測および発熱を行うことで皮膚表面温度の制御を行 っている。ワイヤー保護のために $0.1 \mathrm{~mm} 10$ 分の数ミリの塗料によ って全身が被われているが、塗料の厚みは十分薄いのでワイヤーに よる測定温度は皮膚表面温度と見なせる。設定温度と供給電力量の 間に拘束条件式を用い、式（1）を満たすように環境との熱交換の 収束值として皮膚温を制御している。

$$
\begin{array}{cl}
\mathrm{t}_{\mathrm{s}}=36.4-0.054 \mathrm{Q}_{\mathrm{t}} & \cdots(1) \\
\mathrm{t}_{\mathrm{s}} & \text { :平均皮膚温 }\left({ }^{\circ} \mathrm{C}\right) \\
\mathrm{Q}_{\mathrm{t}} & \text { :着衣時の顕熱損失量 }\left(\mathrm{W} / \mathrm{m}^{2}\right)
\end{array}
$$

サーマルマネキンの制御方法は式（1）による comfort 制御とし た。サーマルマネキンの姿勢はリビングにおいてくつろぐ体勢とし て、投げ足と椅子座とした。サーマルマネキンは、断熱性能 $2.70 \mathrm{~W} /\left(\mathrm{m}^{2} \mathrm{~K}\right)$ 条件の椅子座では北壁から $1,900 \mathrm{~mm}$ 、西壁から $1,600 \mathrm{~mm}$ (西側の床暖房マット中央部) の位置に、その他の条件で は北壁から $1,900 \mathrm{~mm}$ 、東壁から $1,600 \mathrm{~mm}$ (東側の床暖房マット中 央部）の位置に設置した。サーマルマネキンの着衣はスウェット上 下・半袖 $\mathrm{T}$ シャツ・ショーツ・靴下（合計 0.68 clo）とした。各部 位着衣量（基礎熱抵抗）および着衣面積比を表 4 に示す。

\section{4. 実験結果}

実験データは、各条件で暖房を運転させ、環境が安定した状態の 1 2 時間の平均值を使用した。以下、各条件名を「暖房方式・姿勢・ 
[断熱性能 $\left.\left(\mathrm{W} /\left(\mathrm{m}^{2} \mathrm{~K}\right)\right)\right] 」$ とする。

\section{1 温熱環境}

設定温度と比較した室内平均空気温度は、床暖房では-0.8 $1.7^{\circ} \mathrm{C}$ だったが、 $\mathrm{FH}$ 投足[3.72]の $18^{\circ} \mathrm{C}$ 条件では、 $2.4^{\circ} \mathrm{C}$ と差が大きかっ た。エアコンでは $1.9 \sim 4.3^{\circ} \mathrm{C}$ であり、床暖房より設定温度と室内平 均空気温度の差が大きかった。特に設定温度 $24^{\circ} \mathrm{C}$ の条件において は約 $4^{\circ} \mathrm{C}$ の差がみられた。外気温度は $4.5 \sim 4.9^{\circ} \mathrm{C}$ であり、設定温度 の $5^{\circ} \mathrm{C}$ に近い環境であった。床下温度に関しては、模擬基礎を設置 していない $3.04 \mathrm{~W} /\left(\mathrm{m}^{2} \mathrm{~K}\right)$ 条件では、床暖房は $5.8 \sim 6.2^{\circ} \mathrm{C}$ 、エアコン は $5.3 \sim 6.5^{\circ} \mathrm{C}$ とあまり差異はなかったが、他の模擬基礎を設置した 断熱条件では、床暖房は $10.4 \sim 14.0^{\circ} \mathrm{C} 、$ 、アコンは $8.9 \sim 12.2^{\circ} \mathrm{C}$ と なり、床暖房パネルの床下へ逃げる熱が影響して室外環境に差異が 見られた。床暖房パネルから床下へ逃げる熱は床暖房居室の温熱環 境に影響を与えており、投入熱量の算出に関して考慮が必要である。

図 4 にリビング 12 の床面+1,100mm における空気温度と放射温 度の関係を示す。床暖房では空気温度と放射温度はほとんど同じ值 となったが、エアコンでは多くの条件で放射温度の方が空気温度よ りも約 $1^{\circ} \mathrm{C}$ 低い值となった。暖房方式によって、空気温度と放射温 度との差で違いが見られたのは、床暖房では床面を暖めることによ って熱放射により他の壁面も暖まるが、エアコンでは空気温度は上 がるが壁面温度の上昇が小さかったためと考えられる。

図 5 にリビング 12 の位置における、設定温度 $24^{\circ} \mathrm{C}$ 時の上下温度 分布を示す。床面温度は、床暖房の方がエアコンに比べ約 $5^{\circ} \mathrm{C}$ 高い 結果となった。また、床面+100 +2,300mm における空気温度差は、

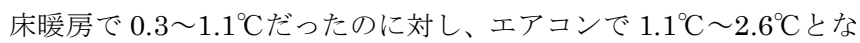
り、床暖房の方がエアコンに比べ上下温度差が小さい結果となった。

\section{2 サーマルマネキン}

\subsection{1 皮膚温}

図 6 にサーマルマネキンの部位別皮膚温を示す。図中の值は、空 気温度と皮膚温との線形関係から補正し、リビング 12 の床面 $+1,100 \mathrm{~mm}$ における空気温度が $24^{\circ} \mathrm{C}$ と仮定した時の值とした。 暖房方式で比較すると、いずれの断熱条件でもほぼ全ての部位にお いてエアコンより床暖房の方が皮膚温が高い結果となり、特に下半 身部位における差が大きかった。その理由として、床暖房では床面 温度がエアコンに比べ約 $5{ }^{\circ} \mathrm{C}$ 高くなっていたことが考えられる。ま た、平均皮膚温も床暖房の方が高くなった。姿勢の違いで比較する と、平均皮膚温は、床暖房ではいずれの姿勢でも約 $34.3^{\circ} \mathrm{C}$ とった のに対し、エアコンでは投げ足の方が約 $0.8^{\circ} \mathrm{C}$ 低くなった。投げ足 は椅子座に比べ、コールドドラフトや床面温度の影響を受けやすく、 エアコンでは床面温度が低かったことが原因と考えられる。床暖房 では各姿勢で床面と接触している部位の皮膚温が高くなった。各部 位の皮膚温分布は、投げ足の方が大きくなった。部位で比較すると、 全ての条件において Hand の皮膚温が最も低くなり、L.Hand より も R.Hand の方が低くなっている条件が多かった。これは、サーマ ルマネキンの右側に開口部があり、冷放射やコールドドラフトの影 響を受けたためだと考えられる。断熱条件で比較すると、椅子[2.70] の条件では床暖房、エアコンともに他の断熱条件より皮膚温が顕著 に低くなっていた。これは、給気口と給気用シリンダーのある西側 壁面に近い位置で測定を行ったことから、コールドドラフトや西側 壁面からの冷放射の影響を強く受けたためだと考えられる。
表 3 測定項目

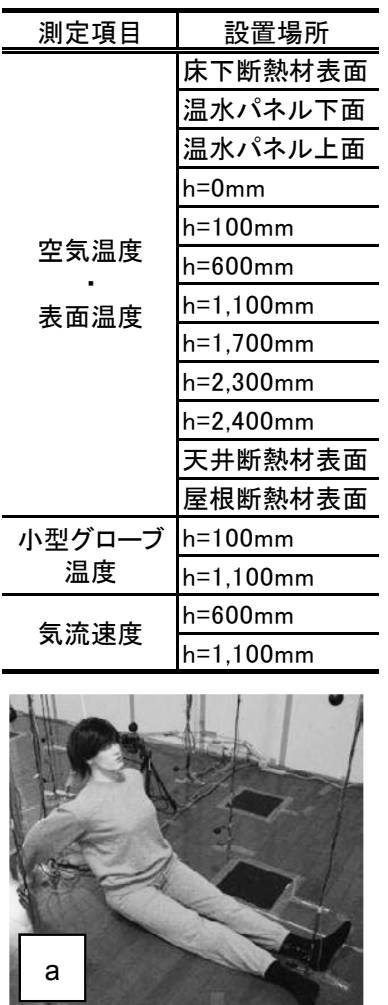

表 4 各部位着衣量・着衣面積比

\begin{tabular}{|c|c|c|}
\hline 部位 & $\begin{array}{c}\text { 着衣量 } \\
\text { [clo] }\end{array}$ & $\begin{array}{l}\text { 着衣面 } \\
\text { 積比 }\end{array}$ \\
\hline L. Foot & 0.26 & 1.08 \\
\hline R. Foot & 0.24 & 1.07 \\
\hline L. Low leg & 0.73 & 1.22 \\
\hline R. Low leg & 0.72 & 1.22 \\
\hline L. Thigh & 0.62 & 1.19 \\
\hline R. Thigh & 0.60 & 1.18 \\
\hline Pelvis & 1.24 & 1.37 \\
\hline Face & 0.00 & 1.00 \\
\hline Crown & 0.00 & 1.00 \\
\hline L. Hand & 0.05 & 1.02 \\
\hline R. Hand & 0.08 & 1.02 \\
\hline L. Forearm & 0.57 & 1.17 \\
\hline R. Forearm & 0.61 & 1.18 \\
\hline L. Upperarm & 0.85 & 1.26 \\
\hline R. Upperarm & 0.95 & 1.29 \\
\hline Chest & 1.48 & 1.44 \\
\hline Back & 1.32 & 1.40 \\
\hline All & 0.68 & - \\
\hline & & \\
\hline
\end{tabular}

図 3 サーマルマネキン
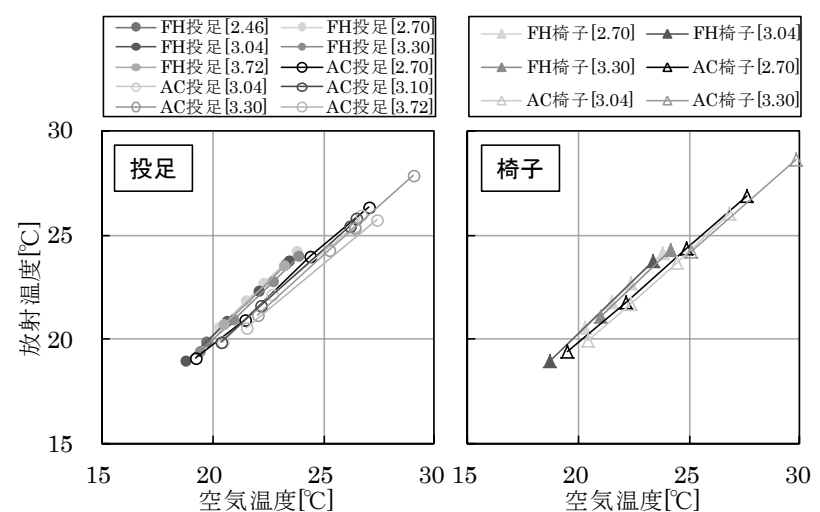

図 4 空気温度と放射温度（リビング 12 , 床面 $+1,100 \mathrm{~mm}$ )

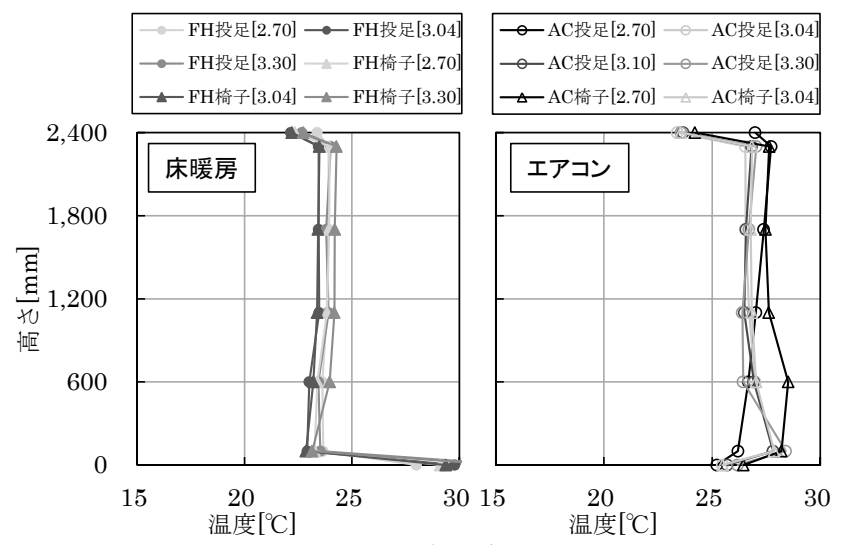

図 5 上下温度分布（リビング 12 , 設定温度 $24^{\circ} \mathrm{C}$ )

\subsection{2 等価温度}

図 7 にリビング 12 の床面+1,100mm における作用温度と等価温 度の関係を示す。作用温度では人体が発熱体であるという点が考慮 されておらず、気流による冷却効果を評価できないため、サーマル 


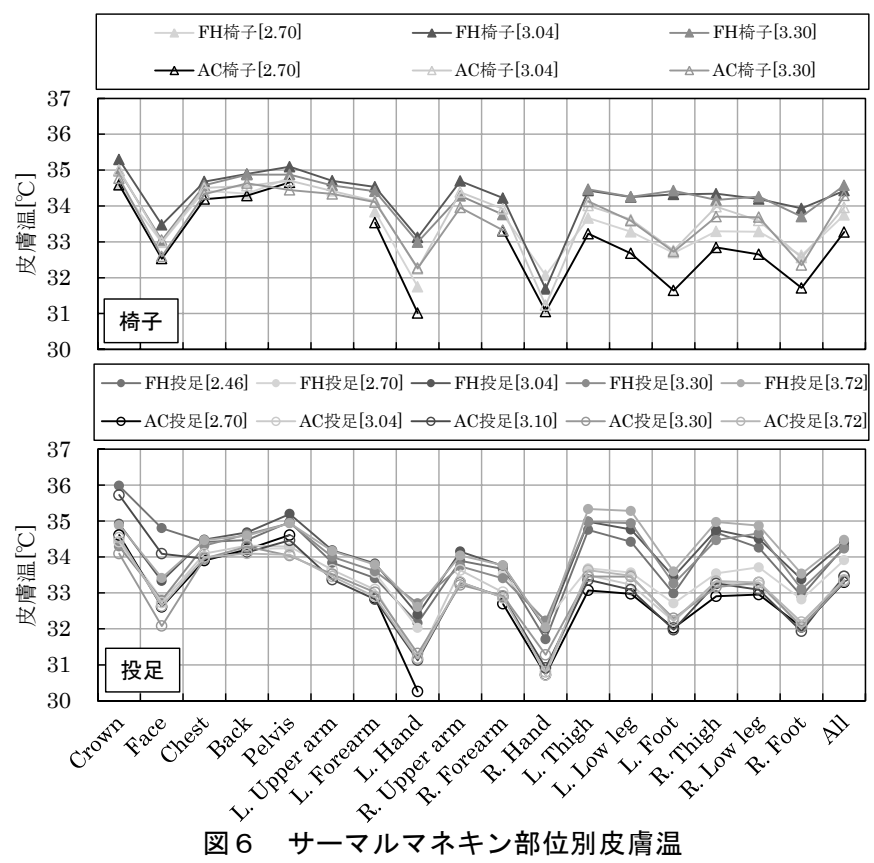

マネキンによって測定された顕熱損失量と式（2）より等価温度を 算出し、比較を行った。式 (2) 中の $\mathrm{I}_{\mathrm{a}}$ は、一定の温熱環境に保た れた温熱環境室内に裸体状態のサーマルマネキンを椅子座で設置し、 測定を行うことで求めた值であり、投げ足と椅子座で同一の值を使 用している。また、室温制御は通常ある点の温度で行われ、分布は 考慮されないことが多いため、本論文の考察ではリビング 12 の床 面+1100mm での作用温度を代表点として比較を行った。一般的に 暖房環境の評価で使用される作用温度と等価温度の比較を行うため に、ここでの作用温度は空気温度、平均放射温度の単純平均とした。

$$
\begin{array}{cl}
\mathrm{t}_{\mathrm{eq}}=\mathrm{t}_{\mathrm{s}}-0.155\left(\mathrm{I}_{\mathrm{cl}}+\right. & \left.\mathrm{I}_{\mathrm{a}} / \mathrm{f}_{\mathrm{cl}}\right) \mathrm{Q}_{\mathrm{t}} \quad \cdots(2) \\
\mathrm{t}_{\mathrm{eq}} & \text { :等価温度 }\left({ }^{\circ} \mathrm{C}\right) \\
\mathrm{I}_{\mathrm{cl}} & \text { :基礎着衣熱抵抗值（clo） } \\
\mathrm{I}_{\mathrm{a}} & \text { :裸体時皮膚表面熱抵抗値（clo） } \\
\mathrm{f}_{\mathrm{cl}} & \text { :着衣面積比（-) }
\end{array}
$$

作用温度が同じ場合の等価温度に関して、暖房方式で比較すると、 全ての条件において床暖房の方が高い結果となり、その差は椅子座 では約 $2^{\circ} \mathrm{C}$ であったが、投げ足では約 $4^{\circ} \mathrm{C}$ であった。姿勢で比較す ると、床暖房ではあまり変化がなかったが、エアコンでは投げ足の 方が約 $2^{\circ} \mathrm{C}$ 低い結果であった。これは、投げ足は椅子座よりコール ドドラフトや床面温度の影響を大きく受け、エアコン条件では床面 温度が低く、平均皮膚温が低くなったためだと考えられる。断熱性 能による違いは、椅子 [2.70]では他の断熱条件と比べて作用温度に 対する等価温度が特に低くなった。これは、椅子 $[2.70]$ 条件では給 気口や給気用シリンダーのある西側壁面側にマネキンを設置したこ とにより、マネキンの皮膚温が低くなったためであると考えられる。

\section{3 空気温度-顕熱損失量}

リビング 12 の床面 $+1,100 \mathrm{~mm}$ における空気温度とサーマルマネ キンの顕熱損失量の関係を図 8、1.1met 条件の熱的中立時の空気温 度を図 9 に示す。投げ足と椅子座の姿勢を考慮し、代謝量は $1.1 \mathrm{met}$ とした。Fangerによれば、熱的中立状態である人体の代謝量 $Q_{m}$ と
平均皮膚温 $\mathrm{t}_{\mathrm{s}}$ の関係は式（3）のようになる 10)。1.1met 時に熱的中 立となる顕熱損失量を式 (1)、（3）より求めると、 $43.7 \mathrm{~W} / \mathrm{m}^{2}$ とな り、それを満たすリビング 12 の床面 $+1,100 \mathrm{~mm}$ における空気温度 は、床暖房では $22.0 \sim 25.0^{\circ} \mathrm{C}$ 、エアコンでは投げ足 $27.1 \sim 27.9^{\circ} \mathrm{C}$ 、 椅子座 $24.4 \sim 28.5^{\circ} \mathrm{C}$ となり、同じ断熱性能で比べると床暖房はエア コンよりも、投げ足では $3.3 \sim 5.5^{\circ} \mathrm{C}$ 、椅子座では $2.4 \sim 3.6^{\circ} \mathrm{C}$ 低い空 気温度で、熱的中立状態を実現できた。

$$
\begin{array}{cc}
\mathrm{t}_{\mathrm{s}}=35.7-0.028 \mathrm{Qm}_{\mathrm{m}} & \cdots(3) \\
\mathrm{Q}_{\mathrm{m}} & \text { :代謝量 }\left(\mathrm{W} / \mathrm{m}^{2}\right)
\end{array}
$$

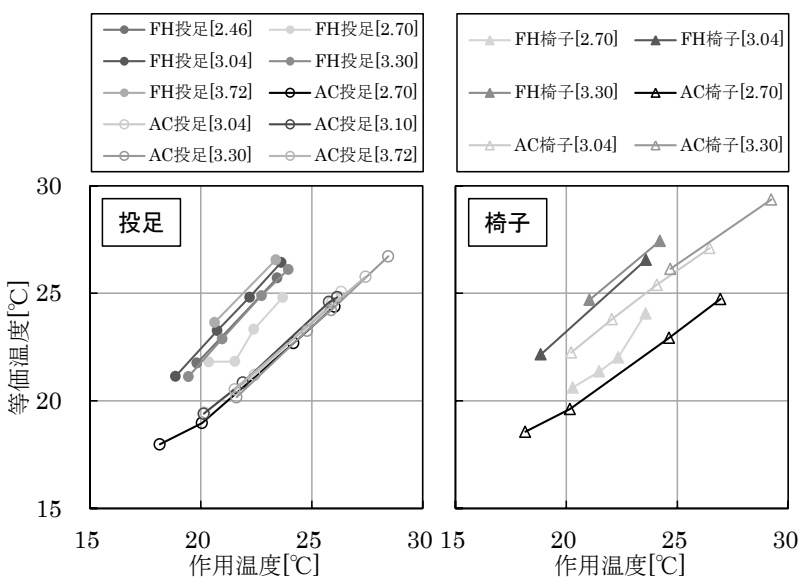

図 7 等価温度と作用温度（リビング 12 , 床面 $+1,100 \mathrm{~mm}$ )

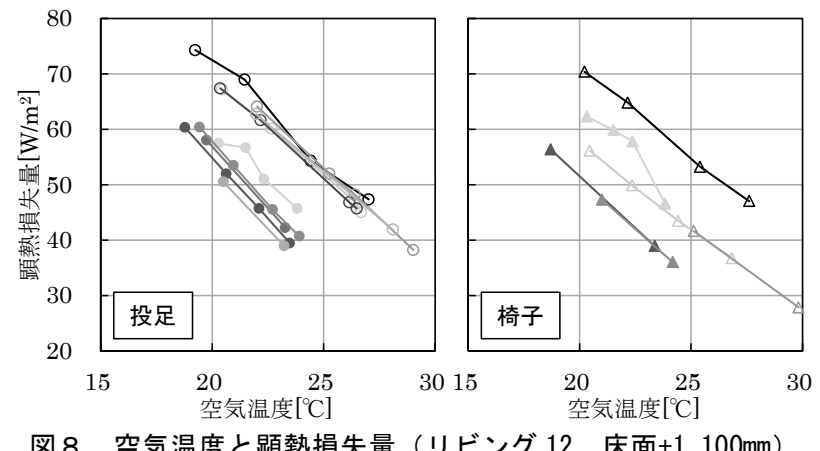

図 8 空気温度と顕熱損失量（リビング 12, 床面 $+1,100 \mathrm{~mm}$ )

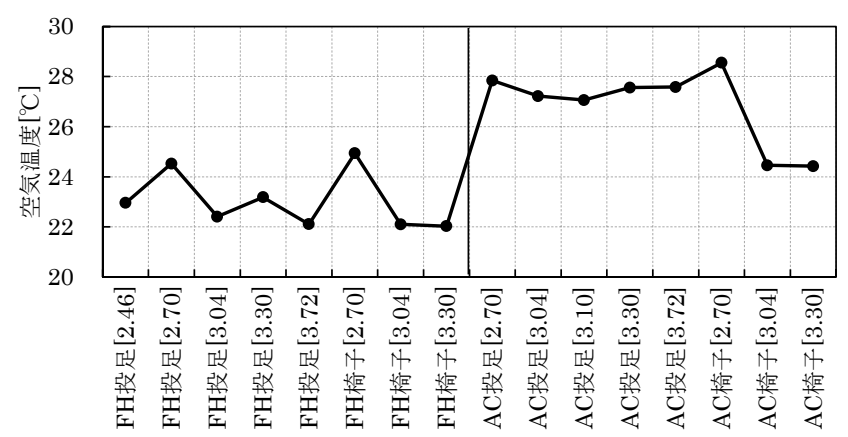

図 $91.1 \mathrm{met}$ 条件熱的中立時の空気温度

\section{4 室内投入熱量}

$1.1 \mathrm{met}$ 条件での熱的中立状態を基準として各暖房方式の室内投 入熱量に関して考察した。1.1met 条件では熱的中立時のサーマルマ ネキンの顕熱損失量は式 (1)、（3）より $43.7 \mathrm{~W} / \mathrm{m}^{2}$ と算出された。 この時の室内投入熱量を、各実験条件で測定された顕熱損失量と室 内投入熱量の線形関係から推定した。各実験条件における室内投入 熱量算出の概念図を図 10 に示寸。床暖房の場合は、温水出入口温 
度差と流量を計測し投入熱量 $\mathrm{W}_{\mathrm{i}}$ を算出し、床上・床下熱量比をか けることで室内投入熱量を算出した。床上・床下熱量比は、施工や 温水マット性能、断熱性能により変化する值であり、今回の実験室 では $\mathrm{a}=0.83$ 注 1) と仮定した。一方、エアコンに関しては 2 次側条件 から室内投入熱量を算出するのが極めて困難なため、リビング床面 積 $20.83 \mathrm{~m}^{2}$ と断熱性能より算出した。

図 11 に熱的中立時の室内投入熱量、表 5 に条件別室内投入熱量 の比較を示す。暖房方式で比較すると、全ての断熱条件において、 床暖房の方が小さい結果となり、投足[3.72]条件において暖房方式 による差が最も大きくなった。いずれの暖房方式においても、断熱 性能が良くなるにつれて室内投入熱量が小さくなったが、FH[3.04] 条件では断熱性能に対して室内投入熱量が大きい傾向が見られた。 これは、FH[3.04]条件は模擬基䃈が設置されておらず、床下から外 部空間に熱が逃げたためだと考えられる。

断熱性能で比較すると、模擬基礎の有無（投足 [2.70]/[3.04]）で は、模擬基礎を設置した方が室内投入熱量は小さくなり、減少率は 床暖房の方がエアコンより高かった。隣室暖房の有無（投足 [3.30]/[3.72]） では、床暖房ではあまり変化がなかったがエアコン では隣室暖房を行った方が室内投入熱量は小さくなった。

姿勢の違いで比較すると、断熱性能の高い $2.70 \mathrm{~W} /\left(\mathrm{m}^{2} \mathrm{~K}\right)$ 条件では、 同程度の室内投入熱量になったが、その他の断熱条件では投げ足よ り椅子座の方が室内投入熱量が小さくなった。これは、断熱性能が 悪くなるほど外壁側からのコールドドラフトの影響は大きくなり、 その影響を床面近傍の方が強く受けるためであると考えられる。図 6 に示したように投げ足ではFoot の皮膚温が低くなっている。

\section{5. まとめ}

1）実験住宅において、断熱性能を 6 条件設定し、人体形状をしたサ ーマルマネキンを用いて、床暖房とエアコンの暖房方式の違いによ る温熱環境を評価した。人体と環境の熱交換の視点から評価・解析 を行うことで、環境が人体に与える影響をより詳細に解析すること ができた。また、熱的中立時の室内投入熱量を算出した。

2) リビング 12 の床上高さ $1,100 \mathrm{~mm}$ における空気温度が $24^{\circ} \mathrm{C}$ と仮 定した時の平均皮膚温は、床暖房の方がエアコンより高く、特に下 半身部位において大きな差が生じた。等価温度に関しては、同じ作 用温度の場合、床暖房の方がエアコンより高かった。サーマルマネ キンの熱的中立条件を満た寸空気温度は、床暖房に比べエアコン投 げ足条件は $3.3 \sim 5.5^{\circ} \mathrm{C}$ 、エアコン椅子条件は $2.4 \sim 3.6^{\circ} \mathrm{C}$ 高くなった。 3）サーマルマネキンの熱的中立条件を満たす室内投入熱量は、床暖 房の方がエアコンよりも小さい結果となった。

\section{謝辞}

本研究は早稲田大学理工学研究所のプロジェクト【12L20】室内 空気質と熱的快適性に関する研究の一部として行われたものである。 本研究を行うに際し、様々な場面で御議論・御協力いただいた、大 森敏明氏、大平昇氏、冨永隆一氏、島貫友貴氏をはじめとする関係 者各位に深く謝意を示します。なお、サーマルマネキンの測定実験 実施および結果の解析の一部は、早稲田大学大学院生（当時）の久 保洋香氏、武部紘樹氏、早稲田大学学部生（当時）の廣瀬文郁氏、 相賀優美子氏が担当しました。
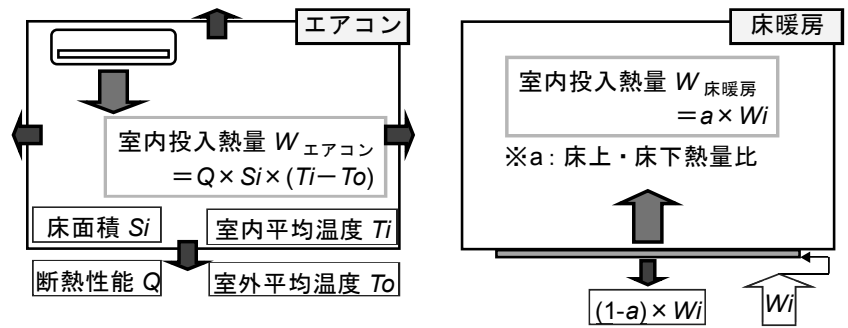

図 10 室内投入熱量算出の概念図

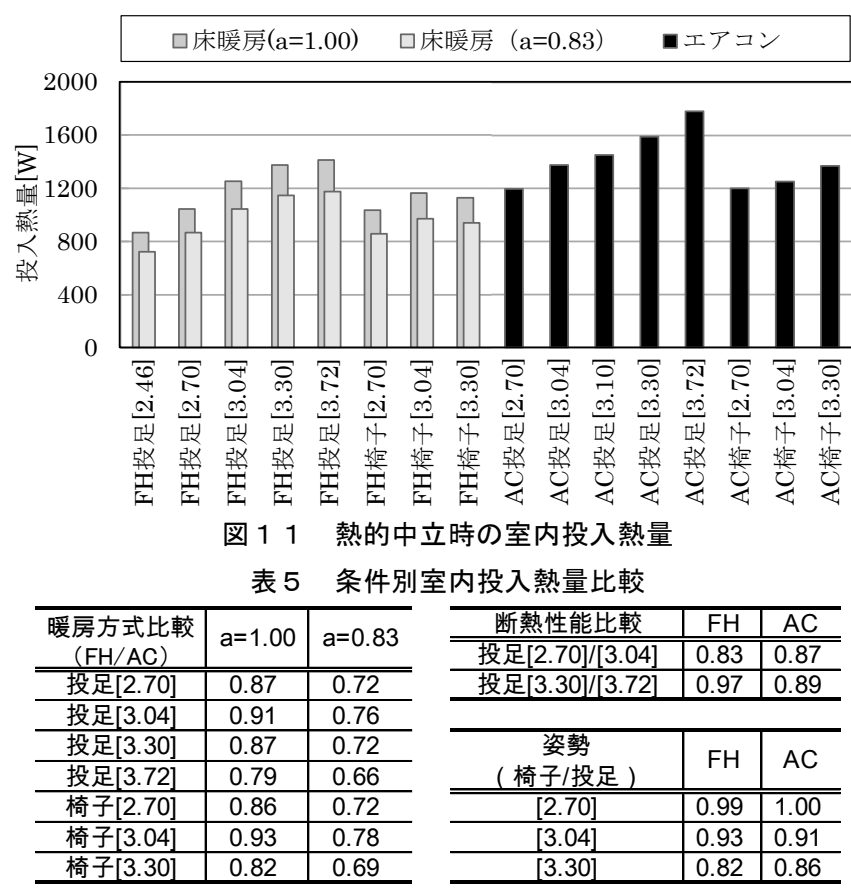

参考文献

1）田辺 他：人体モデルと室内温熱環境評価、日本建築学会環境工学委員 会 熱環境運営委員会第 24 回熱シンポジウム、pp.9-16、1994.11

2) B.W.Olesen、J.Thorshauge : Differences in Comfort Sensations in Spaces Heated by Different Methods. (Danish Experiments) .Proc.of Indoor Climate.ed.by P.O.Fanger and O.Valbjorn.Danish Building Research Institute. pp.645-676、1979

3）秋元 他：低温ふく射暖房・温風暖房・床暖房の快適性とエネルギー消 費量に関する研究 その 1 . エネルギー消費量、空気調和・衛生工学会学術 講演会講演論文集、pp.325-328、1988.9

4）田辺 他：PMV 制御を行なった暖房環境のエネルギー消費量・快適性に 関する実験研究 その 1 . 各種暖房の 3 室同時比較試験、空気調和・衛生工 学会学術講演会講演論文集、pp.333-336、1989.10

5）須藤 他：高気密・高断熱居室と標準居室における各種暖房の温熱環境・ エネルギー消費量に関する研究、空気調和・衛生工学会学術講演会講演論 文集、pp.789-792、1992.10

6）大森 他：対流・放射連成解析による住戸内温熱環境の快適性・エネル ギー消費量総合評価 その 1 . 異なる住宅断熱性能における床暖房・温風暖 房の解析、空気調和・衛生工学会学術講演会講演論文集、pp.865-868、2005.8 7）坂口他：住宅を対象とした床暖房時と温風暖房時の熱収支に関する研 究、日本建築学会環境系論文集 第 628 号、pp.735-742、2008.6

8）稲垣 他：快適性を考慮した異なる暖房方式のエネルギー評価手法に関 する研究その 2 . 人工気候室内実験住宅の概要、日本建築学会大会学術講演 梗概集 D-2 環境工学 II 、pp.437-438、2007.8

9）田辺他：皮膚温度可変型サーマルマネキンによる室内環境評価法に関 する研究、日本建築学会計画系論文報告集 第 448 号、pp.1-8、1993.6

10) Fanger.P.O : Thermal Comfort, Danish Tech. Press、1970

注

注 1）この比率は断熱性により異なると考えられる。またサーマルマネキン の姿勢によって接触面積が変化するため、さらに小さくなる可能性がある。 


\title{
THERMAL COMFORT AND ENERGY INPUT OF HEATING SYSTEM BASED ON EQUIVALENT TEMPERATURE OF A THERMAL MANIKIN
}

\section{Manami SHINOHARA*, Shin-ichi TANABE **, Shin-ichi KAGIYA*** and Kazunori MATSUMAE **** $^{* *}$}

\author{
* Tokyo Gas Co., Ltd., M. Eng. \\ (Former Graduate Student, Dept. of Architecture, Waseda University) \\ ** Prof., Dept. of Architecture, Waseda University, Dr. Eng. \\ *** Tokyo Gas Co., Ltd., Dr. Eng. \\ **** Tokyo Gas Co., Ltd., M. Eng.
}

Recently, environmental considerations have played an increasing role in architecture, and modern residences are becoming more insulated and airtight for energy conservation. Such residences are commonly outfitted with floor heating (radiative) and air conditioning (convective) systems. Ideally, energy conservation should be compatible with thermal comfort. In this study, the thermal environment and comfort in rooms heated by two methods were compared via a thermal manikin experiment, and the energy input required to equalize thermal comfort was investigated. The experiment for the thermal manikin was performed in the living room of an experimental house in an artificial climate chamber. The living room was heated by a floor heating system or an air conditioning system. The thermal insulation performance of the experimental house was set to one of six conditions. The thermal manikin was set in two postures (sedentary and sitting with legs outstretched). The thermal environment, skin temperature and sensible heat loss of the manikin were measured. Mean skin temperature of the thermal manikin was higher under floor heating conditions than under air conditioner conditions, especially in the lower half of the manikin. Furthermore, at the same operating temperature, the equivalent temperature was higher under floor heating conditions than under air conditioner conditions. Consequently, the air temperature of thermal neutrality of the manikin was higher in the air conditioned environment, requiring a higher energy input than under floor heating conditions. The lower efficiency of air conditioning may be attributed to heat loss to the floor. 